\title{
A Brief History of American Indian Business
}

\author{
Charles Harrington \\ University of South Carolina Upstate
}

There is a need to recognize the history and unique and valued contributions to American economic and business history of American Indian business. Indigenous people in the U.S. operate nearly 250,000 businesses, generating in excess of $\$ 40$ billion dollars annually. Their contribution to local, regional, and national economies are considerable, however very little attention has been given to the history of American Indian business, leaving a considerable void in the business education and anthropology literature. This paper provides a cursory overview of the history of native business in the United States, including the challenges, context, and opportunities for further continued development.

\section{INTRODUCTION}

As is necessary for survival and social order, early Native Americans, individually and collectively, were required to provide daily for the needs of their families and their tribes. This responsibility manifest itself in constant effort in areas of agriculture, tool production, assemblage of clothing, creation of appropriate shelter, and other domestic activities. Native people also routinely engaged in trade with other individuals and groups, from both near and far, in order to survive and to make life more comfortable (Weinberg, 2002). Most, if not all, of this trade activity was undertaken in free market situations where individuals came together voluntarily to buy, sell, and trade items that they had manufactured for such purpose.

Anthropological evidence suggests that Native people inhabited and civilized the western hemisphere long before the arrival of European "settlers", and perhaps even to be considered the first to traverse and inhabit North America. With no other "civilized" peoples to serve as examples, the welfare and survival of early Native Americans depended entirely on their own resourcefulness, ingenuity, and persistence. Without the aid of comparative examples, they created and sustained their own culture and societies, technologies and means of production, habitats, and both land and water-based transportation routes. None who have followed their examples and efforts have endured such hardships or challenges

From the origin of principle contact, Europeans experienced significant difficulties in productive interaction with the indigenous population. Considering native people as "savage" and "uncivilized", these early settlers found themselves with little option but to attempt to engage these indigenous people. Short on supplies and grossly outnumbered, the Pilgrims opted to embrace the opportunity to establish beneficial and productive contact, eventually able to gain substantially from trade and barter with the Native Americans (Driver, 1961).

New trade goods represented another big change that European explorers and colonists brought to American Indians (Weinberg, 2002). Soon after meeting their European visitors, Indians became very interested in things that the colonists could provide. In a short time, the Indians began using these new 
materials and products in their everyday lives. Native hunters were eager to trade prepared deer hides and other pelts for lengths of colored cloth. Metal tools such as axes, hoes, and knives became valuable new resources. Soon American Indian men put aside their bows and arrows for European firearms, powder, and lead shot. Trade items like metal pots often were cut up and remade into new tools or weapons. The desire to obtain European goods changed ancient trading patterns. The tradition of simple hunting for food began to become less important than getting animal hides to trade. Soon American Indians became increasingly depended on European items for daily needs.

Regrettably, formal governments intervened in the attempt to formally establish this "New World", asserting itself, aggressively, on Native people. In particular, the British attempted to keep local colonies from negotiating with Indians, tried to avoid conflict by recognizing Indian land claims, and formed alliances with tribes against other colonizing nations

For Native people, "ownership" of the necessities of everyday survival (food, fuel) and the rights inherent therein, resided in groups rather than in individuals. With clear divisions of labor, tribal members worked and specialized in common tasks. Each had an equivalent claim on the tribe's collective supply of goods. A cultural principle of sharing, rather than sole individual possession, was fundamental to social order. Communal rights superseded those of the individual, as kinship assigned equally, life's goods as well as its burdens (Sainsbury, 1973).

The concepts of economic power and wealth were essentially unknown to native tribes. The activities of daily living and the basic economic necessities required therein did not manifest themselves in differential or individual holdings or wealth that would lead to control of supply, markets, or sociopolitical "power". Conversely, prior to the arrival of Europeans in 1492, many Native societies were familiar with social inequality, rank, and in some limited cases, slavery. (Weinberg, 2002)

Commencing with the arrival of Europeans in the $15^{\text {th }}$ century, North America's economy was based on the conquest and plunder of native people. By intentionally separating Native Americans from their ancestral land, settlers established land into a central means of production for America's future "civilized" Bourgeois society. A new rule of unequal private property and property rights displaced communal enjoyment and purpose. It was at this point that social inequality entered into American life, never to depart.

\section{THE HISTORY OF TRADE}

Indian trade has historically been characterized as the web of economic relationships between Europeans and their successors (Euro-Americans and Euro-Canadians) with Native people. Exchange was established between Indians and whites of goods with material and cultural significance as part of diplomatic and economic interactions by two or more parties to secure goods, establish and maintain political treaties, and ensure cohabitation of lands. By this same convention, the Indian trader has been portrayed as a Euro-American or Euro-Canadian male engaged in supplying Native Americans (male and female) with goods and services in exchange for Indian-made or-processed commodities such as furs, pelts, hides, and foodstuffs; geographic information; and, at times, political and social alliances (Sturdevant, 1988).

A more accurate view of Indian trade would be to describe an existing and well established trade practice that was firmly in place long before European contact and colonization. Connecting tribes and regions, pre-Colonial Indian trade involved individual traders as well as trader cultures that served as conduits between tribes separated by considerable distances. Indian traders - female as well as male - met at trading centers located strategically along major river systems and at locales where several tribes seasonally passed en route to hunting, gathering, or fishing grounds. Examples include Cahokia in present-day Illinois, the Mandan-Hidatsa-Arikara villages (often called Middle Missouri Indian towns) in the present-day states of North Dakota and South Dakota, Zuni Pueblo in contemporary New Mexico, and confluences intersecting important waterways such as Sault Sainte Marie and Niagara Falls in the Great Lakes region and the Dalles on the Columbia River. In addition to foodstuffs, fiberware and clayware, 
hides, and exotics ranging from obsidian and flint to seashells and pearls to precious gems and minerals passed hands in Indian lodges and at native trade fairs before A.D. 1500 (Chittenden, 1902).

\section{EARLY EUROPEAN-INDIAN TRADE}

After 1600, these same trails, watercourses, and meeting grounds became routes of European traffic and footprints for forts, factories, and towns placed at strategic points such as Albany, Augusta, Chicago, Detroit, Kodiak, Michilimackinac, Mobile, Natchitoches, Portland (Oregon), San Antonio, and St. Louis. Colonists introduced European mercantile ideas of inventories and profits based upon dynamics of supply and demand, often compromising Native systems, which operated on principles of barter exchange, giftgiving, and reciprocity. Whites who adhered to norms of Native trade did better than those who ignored or bypassed Indian protocol. The French succeeded best in the Indian trade business, becoming social as well as economic partners across North America. Up to the fall of New France in 1760 and beyond, French-Indian relations along the Saint Lawrence and Mississippi Rivers and in the Great Lakes region remained cordial, tied by kinship as well as economic partnerships (Studenvant, 1988).

Spanish, Dutch, English, Russian, and Swedish traders were less successful because of their more rigid expectations: they insisted that Indians conform to European trading standards. All colonists sought furs and hides, including deerskins, for a lucrative European and Cantonese fur market, making the occupation of the white or mixed-blood (French-Indian and Spanish-Indian) trader a common occupational type on all national and ethnic frontiers in North America. Each had government-licensed trading companies with wide powers to expand the respective nation's interests in addition to authority to trade, trap, hunt, and settle. Also, each country had independents, known in French parlance as coureur de bois (runners of the woods). From the Saint Lawrence to the Rio Grande and on to the Pacific Ocean, these "free" trappers and traders trekked and traded, earning reputations for adventure and exploration, and often compromising national interests for personal gain. Across every fur trade frontier, small concerns were absorbed by medium-and large-sized companies, whose workforces were under contract for specific terms of engagement and for set annual salaries (Ewers, 1997).

Many major cities benefitted from this burgeoning Indian trade, including Albany and New York City (Dutch); Detroit, Mobile, Natchez, and Montreal (French); Charleston, Philadelphia, and Savannah (English); Pensacola, Santa Fe, and St. Louis (Spanish); Wilmington, Delaware (Swedish); and Kodiak, Alaska, and Fort Ross, California (Russian).

Native economic dependency did not rest solely upon trade of guns, blankets, kettles, knives, and other utilitarian items with Whites. Nearly all native tribes engaged in European based trade to a certain degree with some tribes prospering and others suffering hardship and economic loss. Throughout the eighteenth century, most tribes of eastern and southeastern North America were locked into the Indian trade as way of life and expected French, British, and Spanish traders to protect their respective trade spheres from outside aggressors and internal rebellion (Ewers, 1997).

\section{TRADE AFTER THE AMERICAN REVOLUTION}

In the aftermath of the American Revolution, Indian trade continued under different national alignments and more restrictive rules. Congress regulated Indian trade under a series of Trade and Intercourse Acts beginning in 1790, establishing government "factories" in the heart of Indian territories in 1796 with the intent of keeping settlers and alcohol out of Indian country. This segregationist approach was abandoned in 1822, allowing large and small companies to compete for Indian furs and favors in the western territories. In both Canada and the United States, independent traders and smaller firms were historically leveraged out of business by oligarchies such as the Montreal-based North West Company; the Philadelphia firm of Baynton, Wharton, and Morgan; and Spanish, Indian, and English traders working for the British firm Panton, Leslie, and Company, based in Florida (Washburn, 1998) .

As smaller, fur-bearing habitats were trapped out or settled, a new economic Indian trade prevailed from 1840 to 1890 on the western plains and prairies. This buffalo-hide trade supplied water-and steam- 
powered factories' demand for leather belts as well as military overcoats, rugs, and blankets. Once the buffalo were hunted near extinction, economic dependency on reservations in Canada and the United States gripped Indian communities, now reliant on annuities and the need to become herders and farmers.

Still, the Indian trade and the Indian trader, part of an international fur industry, continued in Alaska and in Canada's remote Yukon and Northwest Territories, where it remains important, as well as in the eastern Arctic. Across North America, Indians themselves have continued to function as Indian traders, many dealing in arts and crafts, others in horse breeding and trading; others in restoring buffalo, trading calves for other livestock and goods from one reserve to another; and still others in mitigating violations of treaties by swapping further litigation for restoration of tribal lands or monetary compensation (Hanner, 1981).

Deprived of their historic land holdings, Indians also lost control of their traditional livelihood. Agriculture, hunting, and gathering all required land, the principal means of production. They could continue to fashion various productive implements such as spades for digging but these could not be employed without access to land. The same held true for animal traps and other technology. Thus, if they were to remain in their traditional areas of the country, their only alternative was to work for the new owners of the land.

After the Revolutionary War, the new national government had to develop its own Indian policy with respect to Indians. Chief Justice John Marshall set the stage for present Indian policy by asserting that tribes were sovereign nations. In 1831 he wrote in his famous Cherokee Nation v. Georgia opinion that Indian tribes were "nations within a nation," but he went on to call them "domestic dependent nations" implying that they had alienated their power to negotiate with foreign nations by virtue of treaties with the federal government (Anderson \& Parker, 2006). While implying that the tribes had retained their internal powers to govern themselves, Marshall described the relationship between tribes and the United States as "that of a ward to his guardian." Under this interpretation, the federal government attempted to monopolize treaty negotiations with tribes in order to reduce conflicts over land and forced the tribes into a subservient position by declaring them "wards." (Miller, 1988).

The federal government eventually took control of tribal assets by holding them in trust. Tribal sovereignty might have allowed Indians to devise their own property rights and governance structures had the federal government not established the trust relationship with Indians and had it truthfully been willing to grant broad autonomy to Indians over providence and control of their property. The Dawes Act enacted in 1887 had the potential to release Indians from trusteeship by allotting reservation lands to individual Indians in fee simple ownership (Carlson, 1992). However, in 1934 the possibility of fee simple ownership ended with the passage of the Indian Reorganization Act. Since then, the Department of Interior has struggled to programmatically fulfill its trust responsibility and eliminate corruption. Not only does the trust authority raise the cost of managing Indian lands, timber, minerals, and wildlife, it provides opportunities for corruption in the use of those resources and the funds generated therefrom. Because the federal government controls tribal assets, it is not surprising that corruption prevails (McChesney, 1992).

\section{AMERICAN INDIANS AND WAGE LABOR}

Before the European occupation, wage labor did not exist among the Indians. Economic relations were guided primarily by kinship and group solidarity. The fur trade rested on a vast expenditure of Indian labor power but the European traders did not pay much for it. Indian women performed most of the preliminary processing of the skins which were then transported for sale by Indian men. Traders avoided paying for anything by precise wages. The labor force of the fur industry numbered some 160,000 persons but only 2,000 or 1.25 percent were wage or salary workers (Rothney, 1975). Nearly all the rest were Indian people legally regarded as independent contractors. In this way, the company traders could minimize their outlay on labor services. Occasionally, Indians would be hired to serve as porters.

Few Indian workers received any cash wages from their employers. When goods were used as payment, workers were charged some 600 percent over cost (Chittenden, 1977). This led to large debt burdens which often eventuated in debt peonage. The relationship, observes Rhoda Gilman," became far 
more like employment at piece work than independent barter."(Gilman, 1974). Food, guns, and ammunition were doled out in minimal amounts - on the one hand to minimize further financial risk and on the other, to reduce an ever-growing indebtedness. Prices assigned to the goods were known to have been marked up by as much as 2,000 percent.

During the colonial period, European thinkers and philosophers chattered on endlessly about the reputed inability of Native Americans to think rationally. Sometimes they meant the refusal of Natives to join in enriching themselves at the expense of their fellows. At other times they referred to the Native tendency to trap only as many fur animals as they needed instead of building up vast reserves for future trading purposes. Still another meaning was the Natives' willingness to exchange valuable furs for goods that were relatively cheap on European markets.

Aside from the fur trade, Indians could look forward only to occasional day-labor work. In 18thcentury Rhode Island, Indians "provided cheap labor at a degraded status." After the third quarter of the 17th century in New England, "the Indians continued their descent to the position of a sub-proletariat. ...". During the 19th century, Indian labor continued its decline (Salisbury, 1974).

Largely eliminated from east of the Mississippi by the time of the Civil War (1861-1865), Indian laborers found work in some capitalistic industries that arose in the West. Railroad building and maintenance was one such source. In 1880, the Laguna Pueblo signed an agreement with the Atchison, Topeka and Santa Fe Railroad which assured the Pueblo continued employment on railroad lines. Apparently, the agreement was in force for some years. When railroad workers went out on strike in 1922, Laguna workers were shipped to company yards in Richmond, California where they served as strikebreakers while living in boxcars. The building of transcontinental railroads in 1869 and afterwards opened up new mining areas in the West. In southern Arizona, Papagos Indians worked in newly-opened copper mines. Apaches in the same general area worked on farm and mining infrastructure (Knack and Littlefield, 1996).

Indian possession of land was perhaps the single greatest barrier to the formation of a wage-earning working class among Indians. By the 19th century most of that land had been alienated by whites. One principal protection for the Indians still remained: the treaty system. Ever since earliest colonial times, such documents had been negotiated between Indians and whites. With few exceptions, colonists regarded such negotiations as, at best, necessary evils.

In 1831, the U.S. Supreme Court ruled that while Indian tribes were not nations like others, they could be dealt with as "domestic dependent nations," and so the treaty system continued. It lasted, however, for only another forty years. In the meantime, open warfare was waged by the U.S. Army against the "domestic dependent nations". Contrary to the letter and spirit of the Northwest Ordinance of 1787, the federal government expropriated Indian land prodigally. In 1871, Congress resolved "that hereafter no Indian nation or tribe within the territory of the United States shall be acknowledged or recognized as an independent nation, tribe, or power with whom the United States may contract by treaty." (Wunder, 1985). The measure was not retroactive and so existing treaties remained in force.

Federal authorities were increasingly hostile to Indians exercising independent economic action that would counter external pressures brought by the federal government. In the absence of tax revenues, federal land acquisition, and bureaucratic control of natural resources, Indians would be all the more pressed to seek livelihoods as wage workers. As the mirage of Indian sovereignty faded, the reality of proletarianization took more definite shape. At the same time, however, Indians fought to retain the remnants of the treaty system and the special consideration of Indian interests contained within it (Biolosi, 1992).

\section{MODERN AMERICAN INDIAN BUSINESS}

The history of American Indian and Alaska Native business development, up until the last three decades, can be reduced to a general scenario: the overriding focus was on what the federal government could do to "help" Native nations, most of whom had been forced into abject poverty. This approach tended toward grant-making for projects and programs designed by non-Natives and a development 
agenda that was almost wholly federal government-driven. Tribal nations were often caught up in what was essentially a transfer economy, where tribes were left to manage federal monies, if they were able to secure these grants at all. This "projects and grants" mentality, where tribal ventures were often dictated by the federal government's funding priorities rather than their own talents and opportunities, failed to create or support business development in any meaningful way because it did not address the overriding characteristic of Indian Country: its vast heterogeneity. Additionally, this federal grant making approach sparked a grant seeking behavior in many tribes, and ultimately undermined many of the Native nations' own plans since precious tribal resources had to be invested in applying for federal grants in the first place.

A shift in federal policies toward tribal self-determination means that business development in Indian Country today is less dependent on federal government prerogatives. However, business development in Indian Country continues to rely upon numerous important factors ranging from a tribe's access to (or lack of) markets, their development strategy and the institutions in place to support their strategy. This paper will provide an overview of the opportunities and challenges of business development in Indian Country today, with an emphasis on the ways that tribal governments (and individual tribal members) can---and do--- leverage their competitive advantages and core competencies both on and off the reservation

At the most basic level, an economy is the way a society is organized to meet the needs of its people. There are local, regional, national and international economies. Because Native economies are intimately linked with tribal governments and tribal cultures, business development in Indian Country in the United States often depends on the creation of new tribal government institutions, ranging from regulatory commissions to tribal economic development corporations. The structure and effectiveness of these institutions depends upon a range of factors, including cultural appropriateness and political stability.

One of the most common and effective strategies employed by tribal governments in the United States has been the creation of tribal development corporations to manage the business research and development arm of the tribal government, strengthen management and streamline business decision-making. For some tribes, creating a triangular approach works to most efficiently generate, protect and invest tribal capital and assets. Harvard research into nation building supports the general premise that separation of powers can increase accountability and support more efficient governmental functions. However, it is critical that these institutions are also culturally appropriate and tribally generated so they best reflect the goals of the tribe.

While it is difficult to generalize about business development in Indian Country, there is an identifiable pattern of business development among many tribes in the United States. For example, in order to exploit core competencies in hospitality and gaming, many tribal governments have begun business development in gaming-related ventures like hotels, restaurants, spas, RV parks, convention centers and gas stations. These amenities directly enhance the gaming experience while creating additional (and often significant) employment opportunities and revenue streams for the tribal government.

Another business development trend in Indian Country is tourism development more generally, with many tribal governments building and managing golf courses, museums, outlet malls, water parks, convention centers and other businesses that attract visitors to the reservation for gaming and non-gaming purposes.

As had been thoroughly documented, Native nations and peoples have supported, engaged in, and enriched themselves with entrepreneurial private and family oriented economic activities throughout history (Miller, 2008). American Indian cultures and traditions have historically demonstrated the principles of entrepreneurship and do not oppose them as some believe. It is necessary to clarify that Indian cultures have always fostered, encouraged, and supported their tribal people in private economic endeavors, argued for and protected their property rights, and allowed individuals to pursue their own ways (Miller, 2001). Since Indian history and culture encourages and supports entrepreneurship, it underscores the potential benefits and successes that modern American Indian entrepreneurs have achieved. 
The majority of revenue-generating enterprises in Native American communities are tribally owned. However, recently, small individually owned enterprises have also become an increasingly important economic base for these communities. Reports from the Community Development Financial Institutions (CDFI) Fund of the U.S. Department of Treasury characterize Native American communities as America's "domestic emerging market." The CDFI Fund cites the sales growth rates of Native Americanowned business as double the U.S. average and business creation rates as seven times the

U.S. average (Johnson Strategy Group, 2002). Data from the 2007 census shows that since 1997 the number of Native American-owned businesses has risen by $84 \%$ to 197,300 and that their gross incomes have increased by $179 \%$ to $\$ 34.3$ billion.(Minority Business Development Agency, 2008). The Native American Entrepreneurship Project Report, written by First Nations Development Institute (FNDI), estimates that 170,083 of these businesses are microenterprises - businesses that are owned and operated by one person or family, have fewer than five employees, and are usually financed with loans of less than $\$ 50,000$. (National American Indian Housing Council, 2010).

Tribal governments with a limited land base or a remote location are pursuing business development that does not rely on the local market or attracting tourists to the reservation. In many cases, these businesses include development of the tribe's natural resources for export to national or international markets. Examples of these businesses include water bottling plants, farms, orchards, ranches or energy development. Additionally, many tribal governments have purchased or created banks, developed restaurants or hotels and pursued franchising off the reservation, building on their hospitality experience and taking advantage of larger national and international markets.

Finally, there now exist a significant number of agencies, organizations, and entities whose primary existence is to support native entrepreneurs. These organizations include, but are not limited to the National Center for American Indian Enterprise Development, American Indian Business Leaders, American Indian Chamber of Commerce, Harvard Project on American Indian Economic Development, U.S. Department of Commerce Minority Business Development Agency, and the National Congress of American Indians.

\section{CURRENT STATE OF AMERICAN INDIAN/ALASKAN OWNED BUSINESS}

The Survey of Business Owners defines American Indian- and Alaska Native-owned businesses as firms in which American Indians and Alaska Natives own 51 percent or more of the equity, interest or stock of the business. Additional reports from the survey highlighting other minority- and veteran-owned businesses will be issued this year. Subsequently, separate publications will be issued highlighting additional characteristics of all businesses and their owners.

According to the U.S. Census Bureau (2007), there were 236,967 American Indian- and Alaska Native-owned businesses in 2007, an increase of 17.7 percent from 2002. The total number of U.S. businesses increased by 17.9 percent. American Indian- and Alaska Native-owned businesses generated \$34.4 billion in receipts in 2007, a 28.0 percent increase from 2002.

These data come from the Survey of Business Owners: American Indian- and Alaska Native-Owned Businesses: 2007. The survey provides detailed information every five years for American Indian- and Alaska Native-owned businesses, including the number of firms, sales and receipts, number of paid employees and annual payroll.

Data are presented by geographic area (nation, state, county, city and metro area), industry and size of business. Preliminary national and state data were released in July 2010. Among states, in 2007, California had the largest number of American Indian- and Alaska Native-owned businesses with 45,629, accounting for 19.3 percent of the nation's American Indian- and Alaska Native-owned businesses. California was followed by Oklahoma, with 21,194 American Indian- and Alaska Native-owned businesses (8.9 percent) and Texas, with 19,057 (8.0 percent). 
Among counties, Los Angeles, Calif., had the largest number of American Indian- and Alaska Nativeowned businesses with 14,195, accounting for 6.0 percent of all the nation's American Indian- and Alaska Native-owned businesses.

Among metropolitan areas, Los Angeles-Long Beach-Santa Ana, Calif., had the largest number of American Indian- and Alaska Native-owned businesses with 17,634 (7.4 percent), followed by New York-Northern New Jersey-Long Island, N.Y.-N.J.-Pa., with 13,188 (5.6 percent).

Other highlights:

- Of the 236,967 American Indian- and Alaska Native-owned businesses in 2007, 23,704 had paid employees, a decrease of 3.2 percent from 2002. These businesses employed 184,416 people, a decrease of 3.6 percent from 2002. Their payrolls totaled $\$ 5.9$ billion, an increase of 15.4 percent. Receipts from these employer businesses totaled \$27.5 billion, an increase of 25.1 percent.

- In 2007, 213,263 American Indian- and Alaska Native-owned businesses had no paid employees, an increase of 20.6 percent from 2002. These non-employer businesses generated $\$ 6.9$ billion in receipts, an increase of 40.7 percent from 2002.

- The number of American Indian- and Alaska Native-owned businesses with receipts of $\$ 1$ million or more increased 26.7 percent from 3,631 in 2002 to 4,599 in 2007.

- The number of American Indian- and Alaska Native-owned businesses with 100 employees or more decreased by 9.0 percent from 178 to 162 .

- In 2007, 30.5 percent of American Indian- and Alaska Native-owned businesses operated in construction; and repair, maintenance, personal, and laundry services.

- In 2007, construction, retail trade and wholesale trade accounted for 52.9 percent of American Indian- and Alaska Native-owned business receipts.

\section{CONCLUSION}

American Indians have a long and proud history of productive trade, commerce, and entrepreneurship. Existing long before European colonialism, native people created and sustained numerous and complex trade and barter alliances that provided for their various needs. Despite horrendous injustices inflicted upon American Indians at the hands of white settlers and colonial and federal governments, native business and entrepreneurship have thrived. American Indian businesses contribute significantly to the welfare of tribes, play a role in tribal sovereignty and self-determination, and play an important role in the national economy. Although their history and contributions have been largely overlooked by business anthropologists, historians, and scholars of business history and education, American Indian business and business owners have an important and unique place in the fabric of the American economy.

\section{REFERENCES}

Anderson, T. \& Parker, D. (2006). The Wealth of Indian Nations: Economic Performance and Institutions on Reservations. In T. Anderson, B. Benson, and T. Flanagan (eds). Self-Determination: The Other Path for Native Americans, 159-93. Palo Alto: Stanford University Press.

Biolosi, T. (1992).Organizing the Lakota: The Political Economy of the New Deal on the Pine Ridge and Rosebud Reservations. Tucson: University of Arizona Press.

Dean, Lueck. (1992). Land Tenure and Agricultural Productivity on Indian Reservations. Journal of Law and Economics 35(2): 427-454.

Carlson, L. (1992). Learning to Farm: Indian Land Tenure and Farming Before the Dawes Act. In Property Rights and Indian Economies, ed. Terry L. Anderson. Lanham,Md.: Rowman and Littlefield.

Chittenden, H. (1902).The American Fur Trade of the Far West. New York: Francis P. Harper. 
Cornell, S. and. Kalt, S.(2000). Where's the Glue? Institutional and Cultural Foundations of American Indian Economic Development. Journal of Socio-Economics: 29 (443-70).

Driver, H. (1961). Indians of North America. Chicago: University of Chicago Press.

Ewers, J. (1997). Plains Indian History and Culture. Norman: University of Oklahoma Press.

Gilman, R. (1974). “The Fur Trade in the Upper Mississippi Valley, 1630-1850,” Wisconsin Magazine of History, 58 (Autumn, 1974), p. 18.

Goldberg-Ambrose, C. (1997). Planting Tail Feathers: Tribal Survival and Public Law 280. Contemporary American Indian Issues, Volume 6. Los Angeles: University of California at Los Angeles.

Hanner, J. (1981). Government Response to the Buffalo Hide Trade, 1871-1882. Journal of Law and Economics. Vol. 24, No. 2 (Oct.), pp. 239-271.

Knack. M. and Littlefield, A. (1996). Native American Labor. Retrieving History, Rethinking Theory, pp. 4-5 in Littlefield and Knack, eds., Native Americans and Wage Labor, Ethnohistorical Perspectives. Norman: University of Oklahoma Press.

The Johnson Strategy Group, Inc. (2002). CDFI Fund Native American Lending Study Equity Investment Roundtable and Research Report. Washington, DC: Department of the Treasury.

McChesney, F. (1992). Government as Definer of Property Rights: Indian Lands, Ethnic Externalities, and Bureaucratic Budgets. In Property Rights and Indian Economies, ed. Terry L. Anderson. Lanham, Md.: Rowman and Littlefield Publishers.

Miller, M. (1988). Tribal Responses to Federal Land Consolidation Policy. Project Report, Harvard Project on American Indian Economic Development.

Minority Business Development Agency. (2001). State of Minority Business Report. Washington, DC.: Department of Commerce.

National American Indian Housing Council. (2010). Native Americans Often Victims of Predatory Lending. Press Release. Washington, DC: NAIHC

Peters, K. (1996). "Watering the Flower: Laguna Pueblo and the Santa Fe Railroad, 1880-1943," p. 178 in Alice Littlefield and Martha C. Knack, eds., Native Americans and Wage Labor. Ethnohistorical Perspectives. Norman: University of Oklahoma Press.

Rothney, R.G. (1975). Mercantile Capital and the Livelihood of Residents of the Hudson Bay Basin: A Marxist Interpretation (Master's thesis, University of Manitoba). p. 123.

Sainsbury, J. (1975). Indian Labor in Early Rhode Island. New England Quarterly. Vol. 48, pp. 379-80.

Sturtevant, W, (Ed) (1988).Handbook of North American Indians. Vol. 4, Indian-White Relations. Edited by Washburn, W. Washington, D.C.: Smithsonian Institution.

U.S. Department of Commerce. (2007) 2007 Survey of Business Owners- American Indian and AlaskanNative owned Firms: 2007.

Washburn, W. (Ed) (1988). Handbook of North Americans. Vol. 4, History of Indian-White Relations. Smithsonian Institution Press. Washington, D.C.

Weinburg, M. (2002). Indian America. A Short History of American Capitalism. Chicago: New History Press.

Wunder, J. (1985). "No More Treaties: The Resolution of 1871 and the Alteration of Indian Rights to their Homesteads," p. 39 in Wunder, ed., Working the Range. Essays on the History of Western Land Management and the Environment. Westport, CT: Greenwood Press. 